\title{
SIGNIFICANT SOCIAL NETWORKS AND VIOLENCE AGAINST WOMEN: PERSPECTIVE OF PROFESSIONALS FROM A SHELTER
}

\author{
REDES SOCIALES SIGNIFICATIVAS Y VIOLENCIA \\ CONTRA LA MUJER: PERSPECTIVA DE \\ PROFESIONALES DE UNA CASA DE ACOGIDA \\ REDES SOCIAIS SIGNIFICATIVAS E VIOLÊNCIA \\ CONTRA A MULHER: PERSPECTIVA DE \\ PROFISSIONAIS DE UMA CASA-ABRIGO
}

\author{
Scheila Krenkel ${ }^{1}$, Carmen Leontina Ojeda Ocampo Moré ${ }^{1}$ \\ e Leonor Maria Cantera Espinosa ${ }^{2}$ \\ ${ }^{1}$ Universidade Federal de Santa Catarina, Florianópolis/SC, Brasil \\ ${ }^{2}$ Universidade Autônoma de Barcelona, Barcelona, Espanha
}

\begin{abstract}
This qualitative study identified the structural characteristics of the significant social networks constituted in the context of the sheltering of women in situations of violence. Ten professionals were interviewed from a shelter located in the South of Brazil. The organization and analysis of the data was based on the Grounded Theory and software Atlas.ti 7.0. During the women's stay, the professionals noted networks that: (a) wanted to offer help but were unable to ensure safety, (b) made it difficult to leave the shelter for religious or cultural reasons, (c) could help with these women's social reintegration. The professionals considered the significant social networks as key elements for the rescue of bonds broken by the situation of violence.

KEYWORDS: Violence; Violence against Women; Social networks: Shelter; Professional personnel.
\end{abstract}

RESUMEN: Este estudio cualitativo identificó las características estructurales de las redes sociales significativas en torno al proceso de acogida de mujeres en situación de violencia. Se entrevistó 10 profesionales de una casa de acogida de la región Sur de Brasil. La organización y análisis de los datos tuvieran como referencia la teoría fundamentada (grounded theory) y el software Atlas ti.7.o. Las profesionales observaron que las redes: (a) querían ofrecer ayuda, pero no podían proporcionar seguridad, (b) dificultaron la salida de la casa-abrigo por cuestiones religiosas o culturales, (c) podrían ayudar en la reinserción social de las mujeres. Para estos profesionales, las redes sociales significativas son elementos claves para el rescate de los lazos rotos por la situación de violencia.

PALABRAS CLAVES: Violencia; Violencia contra la mujer; Redes sociales; Casa de acogida; Profesionales.

RESUMO: Este estudo qualitativo identificou as características estruturais das redes sociais significativas, configuradas em torno do processo de abrigamento de mulheres em situação de violência. Foram entrevistadas 10 profissionais de uma casa-abrigo localizada na Região Sul do Brasil. A organização e análise dos dados baseou-se na Teoria Fundamentada (Grounded Theory) e software Atlas.ti 7.o. Durante a permanência no local, as profissionais visualizaram redes que: (a) queriam oferecer ajuda, mas não podiam proporcionar segurança, (b) dificultaram a saída da casa-abrigo por questões religiosas ou culturais, (c) poderiam auxiliar na reinserção social das mulheres. As profissionais visualizaram as redes sociais significativas como elemento-chave para o resgate dos vínculos, rompidos pela situação de violência.

PALAVRAS-CHAVE: Violência; Violência contra mulher; Redes sociais; Casa-abrigo; Profissionais. 


\section{Introduction}

According to a study conducted by the World Health Organization (WHO, 2013), it is estimated that $30 \%$ of women are victims of physical and / or sexual violence by an intimate partner. As for age, violence peaks in women between 35 and 44 years, with a predominance between 40 and 44 years. According to the United Nations, violence against women is defined as any gender-based action or conduct that causes physical, sexual or psychological death, injury or suffering, which may occur both in the public and private spheres (UN, 1993). In this sense, Minayo (2006) affirms that, in its anthropological meaning, violence presents itself as an intentional act under the responsibility of who practices it.

The problem of violence against women has become the focus of worldwide discussions in various social segments since the 1970s. In Brazil, feminist social movements gained strength more precisely in the 1980s, occupying spaces for policy and social debates (Rocha, 2007). Since the 1990s, Brazil has created a set of actions and measures implemented based on public policies aimed at preventing, confronting and eliminating violence against women, such as the Specialized Police Station for Women's Care (DEAM), the Special Secretary for Women's Policies, and the Maria da Penha Law (11.340 / 2006), which establishes mechanisms to prohibit and prevent violence against women and the construction of shelters.

Shelters are temporary, safe and confidential places aimed at guaranteeing the physical and psychological integrity of women and their children under the age of 18 who are in situations of violence and are at imminent risk of death (Secretaria de Politícas para Mulheres-SPM, 2011). The shelter is considered a high-complexity service, in which the care provided is based on the recovery of self-esteem, on the promotion of the exercise and reconstruction of citizenship, on the rupture of violence and on the search for equal rights of women as protagonists of their own history (SPM, 2005, 2011).

Shelters are part of the social support network that serves women in situations of violence. In conceptual terms, social support corresponds to the set of formal institutions and organizations that aim to carry out prevention and health promotion actions in the community context (Ornelas, 2008). The actions offered through social support contribute to satisfy some individual needs for affection, esteem, identity, recognition, belonging and / or security (Ornelas, 2008). In this perspective, it is important that there is communication between the institutions that make up the social support network, as they aim for the best organization and planning of the services the professionals provide (Cantera \& Cabezas, 2002; Schraiber, D’ Oliveira, \& Kiss, 2012).

According to the reference term: Support to shelters and reference centers (SPM, 2005), an official document of the federal government - Brazil, the minimum shelter team should consist of: psychologist, social worker, pedagogue / childhood education professional / social educator, cook and driver. The professional activity is based on questions and reflections on gender relations as a historical-cultural product of unequal relations between men and women, which grant legitimacy and sustain violence perpetrated against women (SPM, 2005).

Access to shelters occurs by means of referral through different entry doors, through specialized services or not, which make up the network of support and coping with violence against women. In order to be sent to the shelter, women have to file a complaint against the perpetrator of the violence (police report). Their stay at the shelter is determined case by case, considering the psychological state and safety conditions necessary 
to resume their lives socially (SPM, 2005). After leaving the place, the women should be accompanied by the reference center closest to their home or by a specialized reference center that, together with the departments of different areas in the city, can guarantee access to housing, work and income (SPM, 2011).

The set of devices to cope with violence also include the significant social network of women, understood in this work based on the perspective of Sluzki (2003) as all relationships considered significant, distinguished from other relationships and which are able to offer help and support at difficult times. The social networks include: family, friends, co-workers or fellow students and people from the community, including health and welfare services, neighbors and religious creed (Sluzki, 2003). An individual's social network is one of the central keys to his wellbeing, as it influences health care and the adaptation to crisis situations.

People from the significant social networks can perform one or more functions. They are: social company, which refers to being together or carrying out activities together; emotional support, characterized by positive attitudes, empathy and understanding; cognitive and counseling guide, through the provision of personal / social information and reference models; social regulation, which rescues responsibilities and roles and favors conflict solving; material and service aid, characterized by expert advice, financial assistance or physical assistance; and access to new contacts, which refers to the opening of connection with people and networks that were not part of the individual's network until then (Sluzki, 2003).

According to Sluzki (2003), the reaction of the people the woman turns to for help may influence action or isolation in the face of the violence problem. The comments made by the significant social network may or may not contribute to motivate the individuals to take care of themselves, make decisions to cope with crisis situations, and enable their empowerment, both socially and psychologically (Sluzki, 2003).

Studies on women in situations of violence show that family and friends are the most wanted people in search of help (Alencar-Rodrigues \& Cantera, 2014; Dutra, Prates, Nakamura, \& Villela, 2013; Gomes et al., 2015; Krenkel, Moré, \& Motta, 2015; Sylaska \& Edwards, 2014). When access to the people in the network is difficult due to the situation of violence, social isolation is present in some women's lives. In the context of violence against women, social isolation occurs mainly due to the shame of experiencing this situation, death threats and fear of reprisals by the author of the violence (Alencar-Rodrigues \& Cantera, 2014; Dutra et al., 2013; Moré, 2014) and / or in the case of immigrant women, who are physically distant from their network (Alencar-Rodrigues \& Cantera, 2014; Arnoso, Arnoso, Mazkiaran, \& Irazu, 2012; Reina, Maldonado, \& Lohman, 2013).

On the other hand, the factors related to the isolation or withdrawal of women from the people in their family network include the family's feeling of powerlessness in the face of violence (Rodrigues, Rodrigues, Lira, Couto, \& Diniz, 2016). Another factor is the responsibility the family attributes to the women for the violence experienced, in which they have to obey their husband and maintain the relation (Silva, Padoin, \& Viana, 2015).

Considering the importance of shelter houses and significant social networks in the set of resources for coping with violence against women and the limited social production on the subject in the literature, some questions have arisen concerning the professional practices carried out in this context. How do professionals perceive the social networks of women in the reception process? What is the influence of these networks during the 
women's stay in the shelter? What actions do professionals take to help women recognize their networks and how can they help them when they leave the shelter?

In view of the above, the objective of this study was to identify the structural characteristics of the significant social networks, constituted in the context of the sheltering process of women in situations of violence. The development of this research aimed to contribute to the scientific production on the subject and to foster reflections that support the improvement of the professional intervention strategies in the context of shelters, in order to grant visibility to the functions of the significant social networks, besides reflecting on how the social support is constructed in terms of professional practices in care for women in situations of violence.

\section{Method}

\section{Participants}

This qualitative study involved ten professionals who worked at a shelter for women in situations of violence. Of these participants, eight were social educators, working at the shelter daily on a 12-hour shift system; one was a psychologist and the other a social worker. These last two professionals attended the women weekly while at the shelter and / or after leaving the shelter. The criteria to include the participants in this research were: (a) To be part of the permanent interdisciplinary team (psychologist, social worker, local coordination and pedagogue or childhood education professional or social educator), technical support (nurse, nutritionist and lawyer) or operational staff of the shelter (administrative agent, cook, maintenance and cleaning assistant, guard and driver), SPM, 2005. And (b) To have at least one year of professional experience in care for women in situations of violence and who were sheltered.

Regarding the sociodemographic characteristics of the participants, all were female, aged between 23 and 64 years. As for the marital status, three were married, three single, two divorced, one lived with a fixed partner and another was a widow. Six professionals had children and all reported being religious, predominantly Catholic (seven participants), two declared themselves spiritualists and one Christian. The length of experience at the shelter ranged from 03 to 11 years. With regard to training, seven participants had completed higher education; only two of them worked in their graduation area (psychologist and social worker). Three professionals held a specialization degree, but none focused on working with situations of violence.

\section{Data collection technique}

Data collection was performed through semi-structured interviews. The main themes that guided the interview with the professionals were: (a) sociodemographic data of the participants, (b) identification of people from the significant social network of the sheltered woman, (c) influence of the networks when contacted by the women, (d) functions performed by the networks, (e) forms of help the networks can provide when the women leave the shelter, and (f) recognition and roles the professionals attribute to themselves as part of the sheltered women's network. 


\section{Procedures}

Data collection. The shelter professionals were personally invited to take part in the study and everyone accepted the invitation. The interview with the eight social educators took place at the shelter itself, in a reserved place, during work hours, at the participants' request. Data collection from the psychologist and social worker occurred in the city hall and university library, respectively, both outside their work hours. All interviews were recorded and later transcribed and analyzed.

Data organization and analysis. The organization and analysis of the data were based on the grounded theory, proposed by Strauss and Corbin (2008), with the aid of the qualitative data analysis software Atlas.ti 7.0 (Muhr, 2004). Considering the purposes of grounded theory in the qualitative research scenario (Cho \& Lee, 2014), in this study, the choice of this approach was based on its analytical framework, based on the systematic proposal of coding: open, axial and selective, which favored the best data organization (Strauss \& Corbin, 2008).

Through this process, the results of this study were systematized and organized into four categories of analysis: (a) Significant social networks upon the women's arrival at the shelter, (b) Influence of networks during the women's stay at the shelter, (c) Functions attributed to the significant social networks of the sheltered women and (d) Expected help from the network after the woman leaves the shelter. The categories went through a process of refinement and adequacy, based on the analysis of an experienced researcher and specialist in the field of study.

\section{Ethical Considerations}

This research received approval from the Ethics Committee for Research involving Human Beings of the University and all ethical precepts were followed. In order to preserve the anonymity of the participating professionals and maintain the confidentiality of their information, throughout this article, they are identified using the letter P, followed by the number indicating the interview order and the participant's age (e.g.: P1, 53 years old).

\section{Results}

\section{Significant social networks upon the women's arrival at the shelter}

In order to contextualize the women's sheltering process, it is worth mentioning that, when they arrive at the shelter, they are welcomed by professionals who ask questions about their personal data and their children's (if they have any), the reasons that made them report the author of the violence and who are their reference persons and / or who they would like to inform that they are sheltered, whether family, friends or co-workers, according to the instructions of the Municipal Social Services Department. According to the professionals, some women do not want to warn family members or friends that they are at the shelter, either out of shame, because they "do not want to bother" or because they report that "they have no one." In this case, professionals talk to and explain the women about the importance of telling and talking to people, as they may be concerned about their "disappearance" and / or can assist them in some way. 
When they decide to talk about the people in their network, the women mention family (father, mother, grandparents, siblings, stepparents), friends, neighbors, and church members. Migrant women who are physically separated from their family of origin mainly appoint people outside the family. Most women come to the shelter with a compromised bond with their family of origin, regardless of whether or not the family lives in the city: "Ah, it is very little, when they arrive here they have already severed the bond practically with the whole family, they have already quarreled with their father, with their mother, no one can bear this situation any longer" (P8, 46 years old).

In addition, the professionals mentioned that the women arrive with little or no network or perceive that the people in the network initially do not offer to help them, mainly the relatives who tried to help on other occasions, when they decided to stay in the relationship with the perpetrator of the violence. The professionals also reported that people in the network, especially family and friends, are "saturated", "tired" and that the woman represents a "burden in their lives", which can contribute to the distancing and / or unavailability to assist in this situation.

On the other hand, according to the professionals' report, there are women who mention important people who can help them and that the decision to go to the shelter is due to the danger and death risk they are in. According to the narratives, these women report having strong ties to the family of origin or have other people in their network whom they can count on (friends, neighbors, people from church, co-workers).

As the interviewed professionals reported, women's lack of or refusal to contact people in their significant social network happens more often when they get to the shelter and during the early days of sheltering. Over time, the women will tell their story and mention people who could help them at that time.

Based on the reports, it was observed that, during the women's stay at the shelter, the professionals' work is based on the rescue of the relationship with the family of origin and / or the rapprochement with the family and with the people from the significant social network, with a view to helping the women when they leave the shelter. The following report exemplifies this characteristic of the professional work:

In some more specific situations, we start to create this network with the family, when this bond exists, or if it was very fragile, then we strengthen this bond with the support network, with family, friends or the church because that is something she would have in the community, so that she would be able to overcome this situation of submission. (P9, 30 years old)

\section{Network influence during the women's stay at the shelter}

While staying in the shelter, women can contact people in their network in two ways: by phone or in person. In case of phone calls, a social educator is present throughout the call. Personal contact happens when the sheltered woman mentions that she would like to talk to someone, whether in the family or the network of friends. In this case, a shelter professional calls the person and schedules a time for the meeting, which always takes place at the Municipal Social Services Department. The woman is taken to the place by the driver of the shelter and accompanied by a social educator. Thus, women have the 
opportunity to talk to family members, friends or other people they consider important at the time, also aiming for emotional support or material help to get them out of the shelter.

When questioning the professionals about the influence of this contact for the sheltered women, both positive and negative influences were mentioned. Among the positive influences, the professionals said that contact with significant people contributed to the reduction of anxiety, as the women became more relaxed, happy, relieved, besides feeling more secure and strengthened in relation to their situation of violence.

The professionals more frequently mentioned negative influences as a consequence of the women's contact with their network. These influences were characterized by increased anxiety, nervousness, worry, dismay and tension, as friends and family used to talk about problems or situations involving the perpetrator of the violence or because "the family members say they have already tried to help her and she failed to seize the opportunity" (P4, 55 years old), making them insecure about the possibility of support.

As the participating professionals pointed out, some families have the financial means to help the women, but there is no emotional support, as the woman is being judged for getting separated, that "marriage is forever", that the ideal would be to return to her husband. The same is true for the church, as some religions are against divorce and this sometimes makes it difficult to break the cycle of violence. On the other hand, there are family members, friends and people from church who want to welcome the women but are afraid of the perpetrator of the violence.

\section{Functions attributed to the significant social networks of the sheltered women}

This category showed the functions the professionals attribute to the significant social networks of the sheltered women, in view of the situation of violence and shelter. With regard to the family network, the main function mentioned was material help and services, through financial and housing assistance, so as to provide protection to the women, especially when they want to leave the area and need security to preserve their own life. The emotional support function offered by the family was also mentioned and characterized by care, welcoming and listening to the woman, especially during initial contacts while they were sheltered.

As for the roles of other members of the significant social network, the professionals mentioned that friends, neighbors, people from church and co-workers were the people who offered emotional support, advice and material help to the sheltered women. With regard to emotional support, friends offered affection, hospitality and protection. Advice, in turn, came from friends and neighbors, who were singled out as the main motivators to accuse the author of the violence and seek help. The material help function was performed by the people from the church, through donations of clothing and food for the women and their children after leaving the shelter. Co-workers assisted by donating furniture when the women moved out of the shelter and some bosses did not deduct their wages for the days they were sheltered.

When asked whether they considered themselves as part of the significant social network of the sheltered women, all professionals answered positively, in that they somehow believed they had helped the women to cope with the situation of violence. The functions the shelter professionals mentioned and performed included: emotional support, social company, material and service help, social regulation and cognitive and counseling guide. 
The emotional support function was the most cited, represented by the understanding of the situation of violence, of care, of talking, listening, respecting, offering hugs and affection. "I think that the mere fact that we come, smile, give a hug, in many cases, we really had to hug, because it's such a fragile case" (P8, 54 years old). Related to the role of social company, it was mentioned that they were together and relaxed when they talked about different issues related or not to the violence.

As regards the function of material help and services, the actions related to housing and work for the sheltered women were the most cited. For the participants, material assistance was provided by helping the women to find jobs, rent real estate, search for furniture donated by the community to the home, and donation of food and clothing when the women left the shelter. Another type of material help refers to activities such as painting the sheltered women's hair, doing a manicure and teaching how to apply make-up, embroider and paint.

The social regulation function appears in the participants' statements when they refer to drawing the sheltered women's attention and setting limits regarding situations that occur during daily life at the shelter. In addition, the conversations about the situation of violence were pointed out, aiming at the recovery of the women's role in the relationship with the partner, which goes beyond gender stereotypes. Concomitant with the social regulation function is that of cognitive guide and of advice, by means of orientations regarding medical (corpus delicti exam) and legal procedures (testimony, separation, custody).

\section{Expected help from the Network after the woman leaves the shelter}

According to the professionals, one of the ways in which the members of meaningful social networks could help the women as they leave the shelter is by offering emotional support, described as affection, acceptance, "encouragement to move forward", listening and support for the women's decision regarding the relationship with the perpetrator of violence, whether by maintenance or rupture. The following story illustrates this function: "Sometimes just knowing that there is someone to talk to, to help, that helps a lot, to know that they are not alone out there, that I think helps a lot" (P3, 46 years old).

Another type of help the professionals considered important is helping to provide protection and safety, especially in cases where the former companion continues to threaten the woman's physical integrity after leaving the shelter. According to the professionals interviewed, the significant social network, especially the family, could help the women by taking them into their homes, paying rent for new housing until the women can recover financially and provide food and care for the children.

It is worth mentioning, according to the professionals' perspective, that the types of help vary according to the possibilities of the network, as there are cases where the family does not have the financial resources, when the woman receives help from the people of the church, work and social services. On the other hand, there are cases in which the resources available in social services do not cover all of the women's needs and, then, the professionals consider that family and friends are people who could help financially.

When asked about how the social support network (CRAS, CREAS, Hospitals, Health Clinics, Police Stations, Forums, Guardianship Council) could help the women in situations of violence, the professionals answered that the sectors could treat them better and in a "more humanized" way, understanding the situation of violence they experienced. It 
was also mentioned that the sectors of the social support network could better guide and forward the women, in relation to reporting the perpetrator of the violence, as well as the issues related to the separation process, in addition to the professionals' better awareness of their role and the role of other sectors to work together, providing greater security and protection to the women.

\section{Discussion}

According to the results, the professionals perceive that, when they get to the shelter, the women's relationship with their significant social network is marked by estrangement or disruption, especially with the family. In confrontation with the situation of violence, distancing from the family and extrafamilial networks is characteristic, in the emotional as well as the geographic sense, whether out of fear, shame or guilt, based on a closed system with tensed boundaries (Moré, 2004; Sluzki, 2003). These factors are in line with other studies (Alencar-Rodrigues \& Cantera, 2014; Arnoso et al., 2012; Dutra et al., 2013; Reina, Maldonado, \& Lohman, 2013) and may be associated with the fact that the women arrive "without networks and do not want to let anyone know", as the study participants reported.

The professionals also referred to the fact that the women come to the shelter with little or no bond with the family or extrafamilial network because "nobody bears the situation any longer", because the network is "saturated, tired" of the comings and goings between the woman and her partner, or even because they were afraid of retaliation by the perpetrator. In a study carried out with relatives of women in situations of violence (Rodrigues et al., 2016), the feeling of impotence concerning the problem was reported, out of fear of the perpetrator of the violence and because the woman herself does not accept help. In line with these findings, the research by Silva, Padoin and Viana (2015) revealed that the relatives hold the women accountable for the situation experienced and there is no encouragement to face the violence, as the family, based on its cultural beliefs, considers that the woman has to obey her partner and, therefore, should stay in the relationship.

The rupture or estrangement of the relationships carried out by the women or their network favors social isolation and the reduction of social regulation, which may contribute to sustain the condition of vulnerability and dependence of the woman in relation to the partner (Moré, 2014; Moré, Santos, \& Krenkel, 2014). The proximity to the people in the network favors and expedites the answers about the search for help in the face of a crisis situation, as access to these people becomes easier (Sluzki, 2003). Thus, the absence of networks is considered a hampering factor to escape from the situation of violence, contributing to the maintenance of the problem and increasingly fueling its cycle in a recursive way (Krenkel, Moré, \& Motta, 2015). In this direction, research with women in situations of violence reveals that family and friends are the most contacted network members in search of help (Alencar-Rodrigues \& Cantera, 2014; Gomes et al., 2015; Sylaska \& Edwards, 2014) and help to leverage the resources for the women's empowerment (Gomes et al., 2015).

According to the professionals, most of the sheltered women were not born in that city, a feature that may be related to a small significant social network, as other research has shown (Arnoso et al., 2012; Reina, Maldonado, \& Lohman, 2013). On the other hand, some of these same women had people in their network and asked to warn their friends, people 
from work and from their church about the sheltering. Thus, it can be inferred that women in a situation of violence, in this sociocultural context, managed to build extrafamilial networks and that these turned into potential resources of support to confront the violence.

In the case of women who came to the shelter without a network or with small networks, the professionals' work was developed with a view to the reconstruction or rapprochement of women with the people in their significant social network, so that they could leave the place having support and help needed to rebuild their lives. As women told about their stories and based on the work of the shelter professionals, throughout their stay, the sheltered women expressed interest in contacting the people in their network. For some, this contact made them more relaxed about their stay in the shelter and about the possibility of leaving the place. According to Sluzki (2003), the fact of having a reference group that offers support corroborates the feeling of belonging, wellbeing, self-esteem and favors the adaptation of people to the moments of crisis. It also contributes to the organization of the identity, wellbeing and authorship of one's own life, based on the other's gaze and the feeling that "we exist for someone" (Sluzki, 2003). This, in the context of violence against women, aids in care and coping with the situation.

Other sheltered women, on the other hand, got worried, nervous and discouraged as they got in touch with people in their network, especially when they heard about the perpetrator. In the professionals' opinion, the network should not tell the women about what happens outside the shelter, but make itself available and make efforts to help her. The results of this study also pointed to the influence of the significant social networks, specifically by people from church and relatives, on their beliefs, religious and cultural values, which entailed repercussions for the women's decision to remain in the relationship or get separated from the author of the violence.

For the professionals interviewed, women do not always want to separate from the perpetrator of the violence; they want "merely that the violence ends". There are also women who no longer support the situation and no longer want to stay in the relationship. In both cases, in addition to limiting the work of the professionals who respond to violence-related demands, this kind of influence of family members and people from church can lead to the women's not making the decision about their relationship according to what they feel and really want.

Directly related to the influence of the significant social networks in the context of the violence against women are the functions they perform. For the professionals, the functions offered by the people from the network when the woman is sheltered and the functions that could be offered when they leave the shelter are the same: (a) material and service assistance, particularly financial help; (b) emotional support, mainly through listening and welcoming; and (c) cognitive guidance and counseling, especially with regard to encouraging the reporting of violence. From another perspective, a study of women who were sheltered (Krenkel, Moré, \& Motta, 2015), the acknowledgement of these same functions was observed, which were offered respectively (a) by the people from the shelter and co-workers, (b) family and friends, (c) network of friends and co-workers.

Thus, the results of this study showed that the professionals qualify the functions of the network according to the sheltered women's discourse, in the attempt to view and visualize their departure from the shelter and the social reintegration process. This shows the need for preparation to work with the network theme and to be able to identify other functions and types of help, that is, to know which networks can be activated and how each net- 
work member can help the woman according to her needs, serving as facilitators to face the problem. The results also show that these professionals develop their practices in "learning by doing", in their daily work, and not based on specific training on the subject.

For Arón and Llanos (2004), receiving theoretical training and proper technical-instrumental support to work with the theme of violence is essential, besides contributing to the reduction of the sense of inefficiency or incompetence, characteristics of professional exhaustion. In line with this assertion, frailty is observed in sustaining the support and institutional acceptance of the professionals in this study for them to develop and / or rescue good intervention practices already carried out. An example of these practices would be the promotion of conversations with the sheltered women, so that they could review and re-signify the relationship with their significant social network, both for leaving the shelter and for maintaining that relationship throughout the social reintegration and reconstruction process of their life project.

Among the functions performed by the shelter's own professionals, as people from the women's significant social network, cognitive guidance and counseling are highlighted, characterized by advising the women about legal procedures and also about the relationship with the perpetrator of the violence, and the function of material help and services. Lastly, the professionals referred to the search for employment, housing and income conditions for the women, in compliance with the provisions of the National Policy for Sheltering Women in Violence (SPM, 2011). From another point of view, the same function was performed considering the sheltered women's relation with their body, through the practices carried out and encouraged by the professionals, such as dyeing the hair, having a manicure and learning how to make up.

In historical terms, the woman's body has always been a place to discharge conflicts, a place to exercise power in order to humiliate and dishonor the woman, leaving marks of suffering beyond the signs on the skin (Femenías \& Rossi, 2009). Based on the practices performed, the sheltered women could have another relationship with their own body, reconnecting with themselves and caring for a body that was injured for a long time. The attainment of self-esteem as a result of this process, together with the possibility to self-manage one's life in the face of the changes that have occurred over time, may somehow help to strengthen the women in the face of the violence problem.

In this sense, the study participants also pointed to the necessary improvement of care for the women and articulation among the professionals of the social support network. According to Cantera and Cabezas (2002), cooperation among sectors is fundamental because, when there is no articulation among the sectors, women's problems are solved in an isolated and partial way, which can generate undesirable effects in view of the countless times that their history repeats itself. In addition, this can generate a fragmented view of the woman as to her own situation, generating insecurity and disbelief in the positive solution of the problem, as well as a return to the situation of violence.

Research carried out with professionals from the women's protection network reveals that the spaces for discussion and planning of the cases attended by the different sectors of the social support network are practically nonexistent (Dutra et al., 2013). Besides the possible difficulty in conducting the cases, the turnover of professionals in the network sectors and in the work with violence can happen quite frequently (Arón \& Llanos, 2004). Thus, based on the results presented in this article, the new professionals learn the activities to be developed in their daily work and not based on training about the context they are going to work in. 
Thus, communication among the different sectors through forums and meetings with case discussion and the organization of the work itself, serves as support to direct practices surrounding the situation of violence against women (Schraiber et al. 2012). Following a proposed flow to target women in situations of violence, linked to specific training on violence and social networks, could be useful. This could help, insofar as, when articulation takes place among the sectors of the social support network and the functions of the significant social networks are understood in continuing education, the search for people who can help the women will no longer be an empirical movement and will become an articulated practice to confront the violence.

\section{Final Considerations}

This study aimed to identify the structural characteristics of the significant social networks, constituted around the sheltering of women in situations of violence. The results showed small or non-existent networks when the women came to the shelter, mainly composed of family and friends. They also revealed networks that could not accommodate the women due to a lack of security and others that made it difficult for them to leave the shelter for religious or cultural reasons. In the same sense, the results showed that the visibility and the rescue of the sheltered women's networks were related to the shelter professionals' work, this being a space that favored conversations about the people who are part of the women's relationship network. In view of the recognition of the absence of people who make up the networks of women in situations of violence, the professionals worked through a process of reflection on the importance of rescuing family and extrafamilial bonds, mainly focusing on the support for the women to leave the shelter.

The advance and novelty of this study resides in the possibility of giving voice to the professionals of a shelter house about their related practice to the significant social networks of women sheltered, considering that no specific scientific productions were found, in the Brazilian context. In addition, we showed that, in their own way, the professionals develop their practices aimed at rescuing the bond between the sheltered women and the people from their social networks, but without specific preparation to work with situations of violence and the theme of significant social networks.

It is considered important that the professionals from the social support network identify significant people for women in situations of violence, in order to seek allies to confront the situation, aiming for their better protection. It is also important for the professionals to appropriate the types of functions performed by the members of the networks, contributing to rescue of the bond with the women in situations of violence.

The limitations of the present study are directly related to the working conditions of the professionals involved and the social and economic context in which shelter houses are inserted. In this sense, the recognition of social networks configured around sheltered women, for situations of violence, has a direct relationship with the implementation of these places in the social support network, as a resource for coping violence. Thus, new research could be carried out in different places, aiming to investigate the work of professionals concerning the significant social network of sheltered women in shelters located in other Brazilian regions. In addition, it is suggested that new studies 
be developed, focusing on the work context of shelter professionals, their beliefs and values regarding the issue of violence, in addition to the strategies used to respond to this type of demand.

Regarding the articulation among the sectors of the social support network, it is considered that the functioning and work in a network are based on the awareness-raising of professionals from all sectors, based on the recognition of the limitations of their knowledge and on practices that aim at reflexive and problematizing work. In this sense, training programs for professionals working in situations of violence are useful, in that they can provide technical and instrumental subsidy on violence and significant social networks, which can be included in the set of intervention resources in professional practice.

\section{References}

Alencar-Rodrigues, R. \& Cantera, L. M. S (2014). Cómo mujeres inmigrantes enfrentan la violencia en la relación de pareja? Estudos de Psicologia, 19(1), 4-12.

Arnoso M., Arnoso, A. Mazkiaran, M., \& Irazu, A. (2012). Mujer inmigrante y violencia de género: factores de vulnerabilidad y protección social. Migraciones, 32, 169-200.

Arón, A. M. \& Llanos, M. T. (2004). Cuidar dos que los cuidan: Desgaste profesional cuidado a los equipos que trabajan con violencia. Sistemas Familiares, 20(1-2), 5-15.

Cantera, L. M. \& Cabezas, C. (2002). La red interprofesional como fundamento para una intervención eficaz en el campo de la violencia de género. In M. T. L. Beltrán, M. J. J. Tomé, \& E. M. G. Benítez (Orgs.), Violencia y género (pp. 563-573). Málaga, ESP: Editorial UOC.

Cho, J. Y. \& Lee, E.-H. (2014). Reducing confusion about grounded theory and qualitative content analysis: Similarities and differences. The Qualitative Report, 19(64), 1-20.

Dutra, M. L., Prates, P. L., Nakamura, E., \& Villela, W. V. (2013). A configuração da rede social de mulheres em situação de violência doméstica. Ciência Ẽ Saúde Coletiva, 18(5), 1293-1304.

Femenías, M. L. \& Rossi, P. S. (2009) Poder y violencia sobre el cuerpo de las mujeres. Sociologias, $11(21), 42-65$.

Gomes, N. P., Diniz, N. M. F., Reis, L. A., \& Erdmann, A. L. (2015). Rede social para o enfrentamento da violência conjugal: Representações de mulheres que vivenciam o agravo. Texto \&̊ Contexto Enfermagem, 24(2), 316-324.

Krenkel, S., Moré, C. L. O. O., \& Motta, C. C. L. (2015). The significant social networks of women who have resided in shelters. Paidéia, 25(60), 125-133.

Minayo, M. C. S. (2006). Violência e saúde. Rio de Janeiro: Fiocruz.

Moré, C. L. O. O. (2014). Importância da escuta e construção de redes significativas de apoio à família em situação de violência. In L. C. Fortunato, M. A. Penso, \& M. I. G. Conceição (Orgs.), Abordagem à família no contexto do conselho tutelar (pp. 109-119). São Paulo: Summus.

Moré, C. L. O. O., Santos, A. C. W., \& Krenkel, S. (2014). A rede social significativa de mulheres que denunciaram a violência sofrida no contexto familiar. In R. M. S. Macedo et al. (Orgs.), Família e comunidade: Pesquisa em diferentes contextos (pp. 157-180). Curitiba, Juruá.

Muhr, T. (2004). ATLAS/ti the knowledge workbench. V 5.0 Quick tour for beginners. Berlin: Scientific Software Development. 
Ornelas, J. (2008). Psicologia Comunitária. Lisboa: Fim de Século.

Reina, A. S., Maldonado, M. M., \& Lohman, B. J. (2013). Undocumented Latina networks ad responses to domestic violence in a new immigrant gateway: Toward a place-specific analysis. Violence Against Women, 19(12), 1472-1497.

Rocha, L. M. L. N. (2007). Casas-abrigo no enfrentamento da violência de gênero. São Paulo: Veras Editora.

Rodrigues, V. P., Rodrigues, A. D., Lira, M. O. S. C., Couto, T. M., \& Diniz, N. M. F. (2016). Relações familiares no contexto da violência de gênero. Texto E̊ Contexto Enfermagem, 25(3), $1-9$.

Schraiber, L. B., D’ Oliveira, A. F. P. L., Hanada, H., \& Kiss, L. (2012). Assistência a mulheres em situação de violência - da trama de serviços a rede intersetorial. Revista Athenea Digital, $12(3), 237-254$.

Secretaria de Políticas para as Mulheres - SPM. (2005). Termo de referência: Apoio a casas abrigo e centros de referência. Brasília, DF: Autor.

Secretaria de Políticas para as Mulheres - SPM. (2011). Diretrizes Nacionais para o abrigamento de mulheres em situação de risco e violência. Brasília, DF: Autor.

Silva, E. B., Padoin, S. M. M., \& Viana, L. A. C. (2015).Violence against women and care practice in the perception of the health professionals. Texto \& Contexto Enfermagem, 24(1), 229-237.

Sluzki, C. E. (2003). A rede social na prática sistêmica: alternativas terapêuticas. São Paulo: Casa do Psicólogo.

Strauss, A. \& Corbin, J. (2008). Pesquisa qualitativa: técnicas e procedimentos para o desenvolvimento de teoria fundamentada (2a ed.). Porto Alegre: Artmed.

Sylaska, K. M. \& Edwards, K. M. (2014). Disclosure of intimate partner violence to informal social support network members: A review of the literature. Trauma, Violence and Abuse, 15(1), 3-21.

United Nations - UN. (1993). Declaration on the elimination of violence against women. General Assembly Resolution nº. A/RES/48/104. Geneva: Author.

World Health Organization - WHO. (2013). Global and regional estimates of violence against women: prevalence and health effects of intimate partner violence and non-partner sexual violence. Geneva: Author. 


\section{SCHEILA KRENKEL}

\section{https://orcid.org/OOOO-0002-2976-7665}

Master and $\mathrm{PhD}$ in Psychology from the Postgraduate Program in Psychology at Universidade Federal de Santa Catarina, Brazil, with a splitsite doctoral internship period with a CAPES scholarship at the Autonomous University of Barcelona (UAB), Spain. Scheila is currently a postdoctoral student (PNPD-CAPES) at the Universidade Federal de Santa Catarina (LABSFAC/UFSC), Brazil.

Address: Department of Psychology/CFH/UFSC. University Campus, Trindade. Florianópolis/SC, Brazil. 88040-900

E-mail: scheilakrenkel@gmail.com

\section{CARMEN LEONTINA OJEDA OCAMPO MORÉ https://orcid.org/O000-0003-2468-8180}

Master and PhD in Psychology (Clinical Psychology) from PUC-SP, Brazil, with a split-site doctoral internship period at the University of Los Angeles and the Mental Research Institute, California, United States. She has a postdoctoral degree from the Autonomous University of Barcelona and the Faculty of Psychology of the University of Lisbon, Portugal. Additionally, Carmen is a professor of the Undergraduate and Graduate Programs in Psychology at the Universidade Federal de Santa Catarina, Brazil.

E-mail: carmenloom@gmail.com

\section{LEONOR MARIA CANTERA ESPINOSA}

https://orcid.org/OOOO-0002-4541-5993

PhD from the University of Puerto Rico and PhD in Social Psychology with extraordinary award from UAB, Spain (2004). Full Professor at the Department of Social Psychology at the Faculty of Psychology at the Autonomous University of Barcelona (UAB) and coordinator of the research team VIPAT - Violence in affective couple relationships and at work.

E-mail:leonor.cantera@gmail.com

\begin{tabular}{|c|c|}
\hline History & $\begin{array}{l}\text { Submission date: 12/16/2017 } \\
\text { Revision date: 07/08/2018 } \\
\text { Acceptance date: 11/11/2019 }\end{array}$ \\
\hline $\begin{array}{l}\text { Authors' } \\
\text { Contributions }\end{array}$ & $\begin{array}{l}\text { Conception: S.K .; C.L.O.O.M. } \\
\text { Data collection: S.K. } \\
\text { Data Analysis: S.K .; C.L.O.O.M .; L.M.C.E. } \\
\text { Writing of the manuscript: S.K .; C.L.O.O.M .; L.M.C.E. } \\
\text { Final approval of the manus cript: S.K .; C.L.O.O.M .; L.M.C.E. }\end{array}$ \\
\hline $\begin{array}{l}\text { Funding/ } \\
\text { Financial Support }\end{array}$ & $\begin{array}{l}\text { Brazilian Scientific and Technological Development } \\
\text { Council }(\mathrm{CNPq}-\text { Process 140434) and Coordination for } \\
\text { the Improvement of Higher Education Personnel (CAPES) } \\
\text { - pprimary author's sandwich doctorate grant (Process } \\
88881.133060) \text {. }\end{array}$ \\
\hline $\begin{array}{l}\text { Image Usage } \\
\text { Consent }\end{array}$ & Not applicable. \\
\hline
\end{tabular}

